Historic, Archive Document

Do not assume content reflects current scientific knowledge, policies, or practices. 



\section{YAGER SEED and NURSERY BOOK}

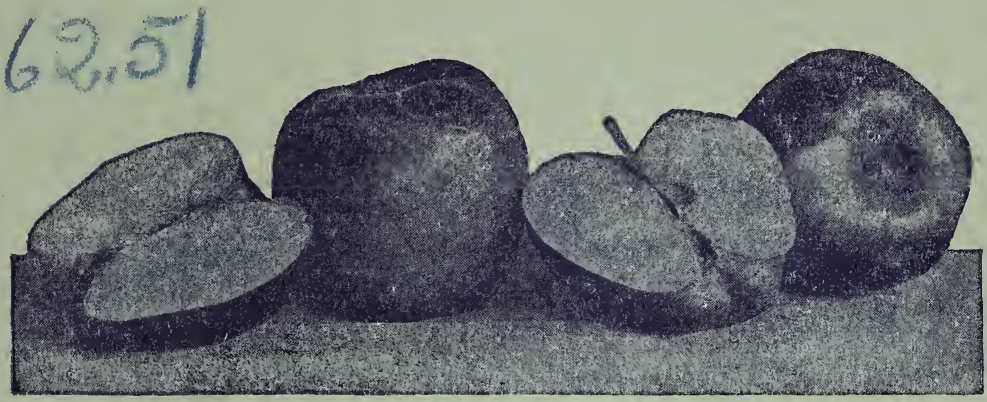

Trees and Fruits of all kinds ${ }^{1} \mathrm{R}, \mathrm{R}, \mathrm{R}$ + FFB $9192{ }^{\star} \star$

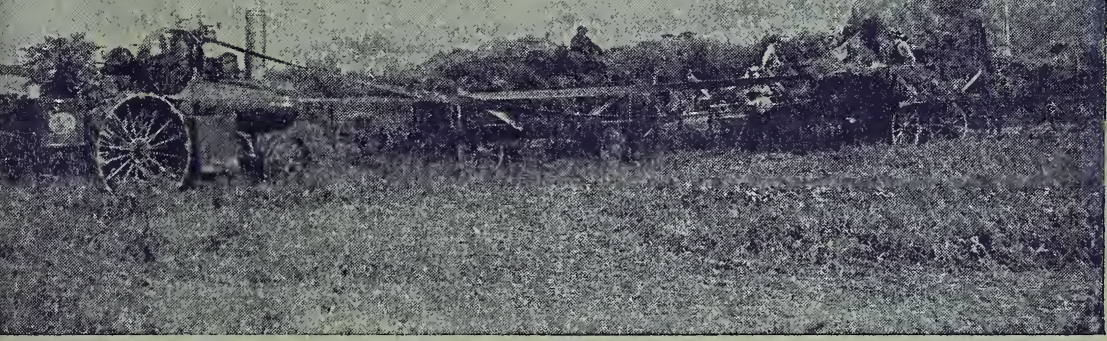

\section{Seed for Farmers}




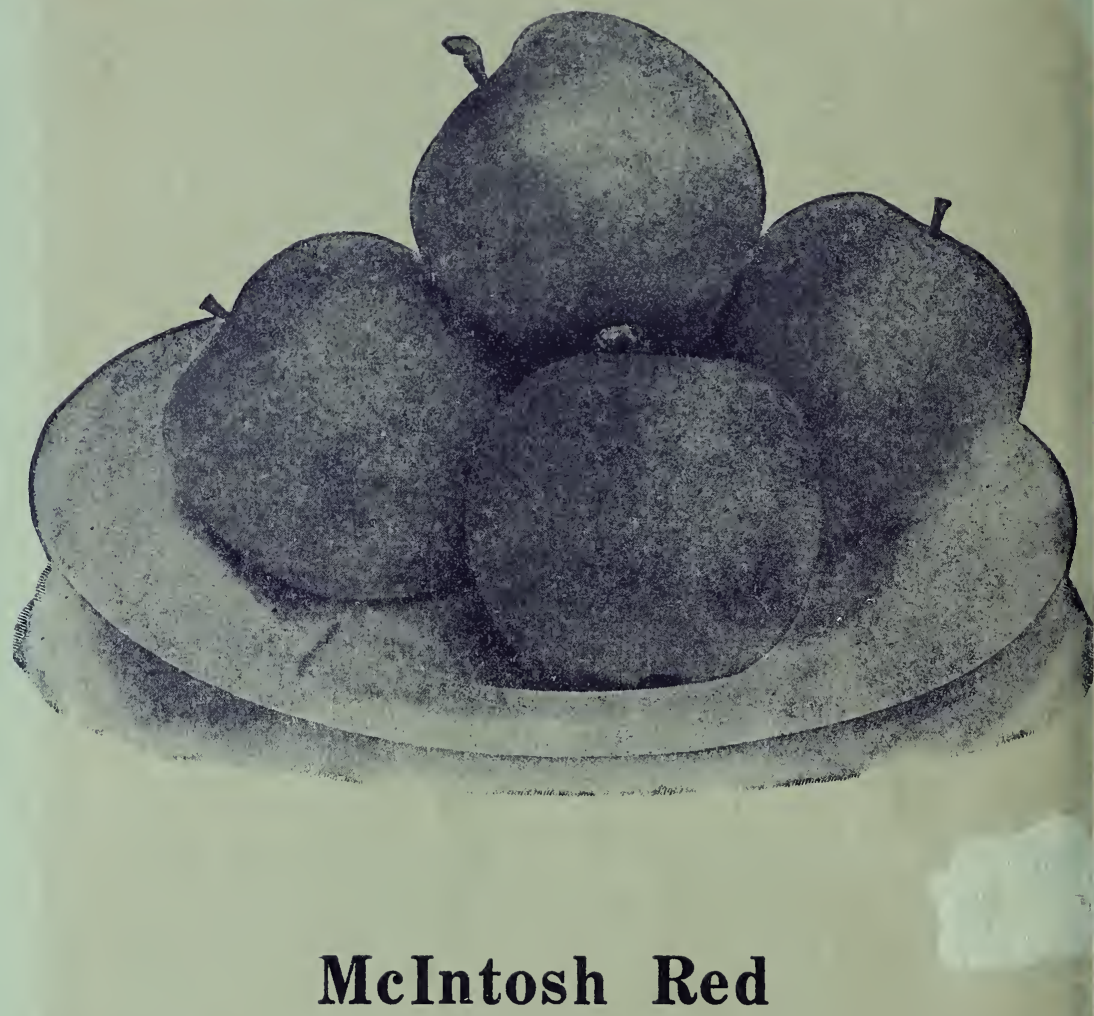

Why do you buy your apples that come from Oregon or some other western state?

Did you know that apples grown in our Eastern Nebraska soil have a better flavor than our shipped-in apples? Eastern Nebraska soil has got the world beaten for producing high quality apples. This has been proven by the best apple experts.

If you own a farm, you ought to plant some apple trees, or even if you have a city lot. The first investment is small, and the returns are large.

You save about half when you buy your trees from me, and you get good trees at that. The quality is high and the price is low. Hundreds of customers will testify to this.

The customary way of buying stock through tree peddlers, is a waste of money. You have my guarantee that my nursery stock is first-class in every respect.

Hundreds of people, who live near enough, come to my nursery every year and personally select the trees, plants and shrubs that are advertised in this catalog. I will be mighty glad to have you do the same.

Try a few of my McIntosh Red apple trees. This is one of the best winter apples grown in Eastern Nebraska. Price, same as other sorts. 



\section{Yager's Seed Prices for 1929}

ALFALFA

Per. Lb. Per. Bus.

Standard Nebr. (Reliable Grade) 20c

South Dakota (Standard Grade)_ 26c

Turkestan (Genuine Imported) --1 30c

North Dakota (Very Hardy) _..- 31c

Bee Hive, Sealed Bags (Extra

Hardy)

Grimm, Sealed Bags (U. S.

Verified)

SWEET GLOVER (Scarified)

Choice, White (Scarified)_-_-_-- 8c

Special, White (Scarified) _-..-- 9c

Faricy, White (Scarified)_...-.- $9 \frac{1}{2} \mathbf{c}$

Extra Fancy, White (Scarified) _- 10c

Fancy, Yellow (Scarified) _...-- 10c

$\$ 12.00$

15.60

18.00

18.60

19.20

28.20

4.80

5.40

5.70

6.00

6.00

RED CLOVER, (Home Grown)

Standard, Fancy Grade

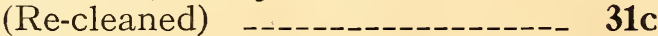

Extra Fancy Grade (Re-cleaned) 32c

18.60

19.20

ALSIKE GLOVER

Standard Grade _..._-_._-_._-_ 31c

Extra Fancy Grade

18.60

22.20

TIMOTHY (Home Grown)

New Crop, High Grade

3.60

TIMOTHY AND ALSIKE (Mixed)

(20\% or more Alsike) _..--_-_-- 14c

RAPE, Dwarf Essex (Fancy -..-- 10c

BROME GRASS (Bromus Inermis) _.._14c

SUDAN GRASS (Very Fancy)

40 Lbs. Bus.

$8 \mathrm{c}$

GERMAN MILLET (High Quality)_ 4c

6.30

5.00

1.96

WHITE DUTCH CLOVER (For

$\begin{array}{cc}\text { Lawn) } \\ \text { KY. BLUE GRASS (For Lawn) }-{ }_{---} & 45 \mathrm{c}\end{array}$

3.20

2.00

NOTE: Above prices hold good till March 1, 1929. After this date, write for new prices.

(My Office is in same Block as Monnich's Garage) Phone 373

Yager Nursery \& Seed Company FREMONT, NEBRASKA 


\section{A Little Visit With the "Boss"}

TEAR after year I keep sending out my little TREE and SEED BOOK in Eastern Nebraska. Perhaps you have been getting the BOOK regularly, or this may be the first
one you have had. But in either case, I hope that you will find some items that you will be interested in.

This little BOOK goes chiefly to farmers, as they are the backbone of Nebraska's prosperity. The money in our banks, the buildings in our cities, manufacturing enterprises, and all lines of endeavor, are dependent upon what the farmer produces from the soil in Eastern Nebraska.

There is a lot of difference between LUXURIES and NECESSITIES. When you buy a piano, a radio or an automobile, it is worth less money the next day than when you bought it, because these are semi-luxuries. When you sow good SEED on your farm, you have made an investment that returns good dividends. This also is true in planting an orchard, as both of these are necessities.

My motto for thirty years, has been, "Give every man a square deal," who makes a purchase of me, so that when he is in need of more TREES or SEED, he will instinctively think of Yager.

What I am trying to say, is, that all business men must necessarily be honest, or their business will languish and die, because honesty is the best and only policy.

Once in awhile a "shyster" will apparently succeed for a short time, but he soon passes out of the picture.

Days and days, and parts of nights, are spent by me in my endeavor to secure the best and purest SEED for you. This SEED is usually bought in big car lots for spot cash, at the lowest possible prices, quality considered, and I try to pass a part of this saving on to you.

This farming business is a serious affair. When you go to the field to sow your SEED, you want to know that it is good and will grow. If not, there will be no harvest. Just send in and get my samples, and get samples and prices from the other fellows also, and you be the judge.

Now don't throw this little BOOK away when you get it, because you think it is too early to buy NURSERY STOCK or SEED, but lay it up on the clock shelf as you may want to refer to it later.

I thank you for reading my letter, and would be glad to hear from you at any time. Yours truly,

J. A. YAGER. 


\section{Read This Page Carefully}

HOW TO ORDER. For your convenience we enclose an Envelope and Order Sheet, to be used when ordering from this book, but you can send the order on ANY kind of paper, in any kind of an envelope. We will get the order, and you will get the goods you want, we guarantee that.

WHEN TO ORDER. Place your order as early as possible, as delay and confusion are thus avoided and better service is assured.

ACKNOWLEDGMENT. When we get your order we write you immediately, stating the amount of money received, and giving the approximate time of shipment.

AM I RESPONSIBLE. You have a right to know. Three Fremont Banks say I am RELIABLE and that I keep all my promises. Your own banker has my "rating," ask him about Yager. You take no chances whatever.

MY TERMS. Cash should accompany your order, but the money is yours till you get the goods. You may remit by DRAFT, EXPRESS ORDER, POST OFFICE ORDER or PERSONAL CHECK, (in which case add 10c exchange.)

OUR LOCATION. Fremont, Nebraska is in Dodge Co., being 37 miles Northwest of Omaha and 50 miles north of Lincoln.

SHIPPING FACILITIES. Three railroads enter Fremont, namely Union Pacific, B. \& M., and the C. \& N. W., thus giving good service to all points. Also we have the American Railway Express Co.

GUARANTEE. I promise that all Nursery Stock will reach you in good live condition. Each variety will be plainly marked, and everything will be packed in the best possible manner. Errors on our part will be cheerfully rectified.

AGENTS. This book is my only salesman for nursery stock, so no agent has authority to represent my nursery, but I have a number of salesmen taking orders for my FARM SEED.

REPLACING STOCK. I do not replace nursery stock. When the agent sells you an order, he promises to replace stock that dies, but the price he asks you covers his expenses of replacing, so you really pay for the replace whether you get it or not. So you get more for your money from me than from the nursery that replaces at half price.

FREE FREIGHT. The Freight or Express will be paid by me on all nursery orders (but not Seed) amounting to $\$ 10.00$. Neighbors may combine orders and get FREE DELIVERY.

INSPECTION. All my nursery stock has been inspected by the official known as the State Entomologist, who has given me a "Clean bill of health."

CLAIMS AND DELAYS. If a shipment should arrive in a damaged condition, have the Railroad or Express Agent note same on your receipt, and write us at once. We notify you the day shipment is made. If goods do not arrive in a reasonable time, notify us, so we can trace same. 


\section{APPLES}

A few dollars invested in apple trees now will return much pleasure, profit and health in the years to come.

I list only the hardiest and best varieties for Nebraska, omitting long descriptions.

Those marked with an (*) are first choice. All my trees are grown here at Fremont and are equal in quality with any sold at much higher prices. Thousands of YAGER'S trees are growing in Eastern Nebraska. They grow. They bear and satisfy.

\section{PRICES ON APPLES AND CRABS}

XX 6 ft. 3 year old select.

Each Per 10

5 to $6 \mathrm{ft}$. 3 year old No. 1 $\$ 0.65$

4 to $5 \mathrm{ft}$. 2 year old choice

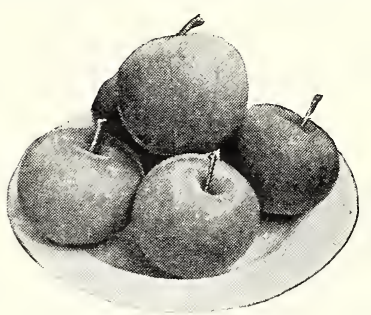

NOTE: You may select ten or more of different varieties at the ten rate. CRABS same price as apples.

\section{SUMMER APPLES}

* DCCHEss. Very hardy, red striped. Best early apple. Ripens in July.

YELLOW TRANSPARENT. Best yellow summer apple. Bears early. Ripe at harvest.

EARLY HARVEST. Pale yellow. Good eating apple. Ripens in July.

\section{FALL APPLES}

MAIDEN BLCSH. Good size. Bears every year. Red cheek. Ripens in September.

* WEALTHY. Dark red cheek. Large size. Bears young. Best fall apple. Ripens in October.

SNOW (Fameuse). Bright rea. White flesh. Spicy. Ripens in October.

PRICES SWEET. Red splashed. Best fall sweet. Hardy. Ripens in September.

\section{WINTER APPLES}

* JONATHAN. Good size. Glossy dark red. Spicy and delicious. One of the best. Keeps until March.

* DELICIOUS. Greatest winter apple. Beautiful red. Best quality. Keeps until May.

BEN DAVIS. Good old standby. Red cheek. Bears anmually. Makes most bushels. Keeps until April.

NORTHWESTERN GREENING. Very large. Greenish yellow. Hardy. Strong grower. Fine for baking. Keeps until March.

* WINESAP. Dark red. Fair size. Tree hardy. Very juicy. Keeps until May.

* GRIMES GOLDEN. Rich yellow. Good size. Spicy. Hardy. Keeps until February.

JANET (Geniton). Small size. Pale green and red. Crisp and tender. Late keeper. Keeps until May.

\section{CRAB APPLES}

* WhITNEY No. 20. Largest size. Juicy but not sour. Hardy everywhere. The best crab. Ripens in August.

HYSLOP. Blood red. Hardy. Good for pickles and jelly. Ripens in September.

If you live within driving distance of Fremont, I invite you to come to my nursery and seed house and judge for yourself whether my goods and prices are reasonable and fair. 


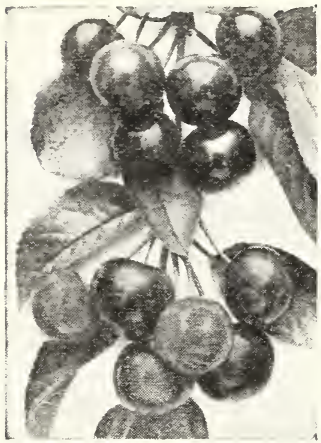

\section{CHERRIES}

The cherry bears at an early age; is not subject to insect injury. A few trees will supply the table, and the balance may be canned for winter use. Best varieties are listed here. Our trees are nice, smooth, well rooted and vigorous. Starred varieties are first choice.

\section{PRICES ON CHERRY TREES}

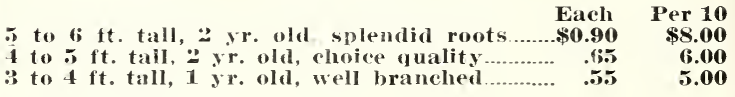

* EARLI RICHMoND. Large red. The best old sort. Earliest to ripen. Bears young. Very hardy. Ripens in June.

* Ifrge Moxtioraycx. Largest size. Iight red color. Bears early. Ripens in June. (Ripens after Early Richmond).

* ExGLish Moreldo. Medium size. Nearly black. Very juicy and rich. Splendid bearer. Best lite kind. Ripens in July.

MAY DIKE. Best sweet cherry. Light red fruit. Upright grower. Juicy and fine. Ripens in July.

\section{APRICOTS}

This is one of our finest hardy fruits, both for canning and immediate use from the tree. The best varieties are the two Russian types listed below.

\section{PRICES ON APRICOT TREES}

5 to fi ft. tall, \& year old, selected.

Each Per 10

4 to 5 ft. tall, ¿2 year old, standard

$\$ 0.90$ \$S.50

* MLEXXDER. (Russian). Medium to small. Light orange, yellow flecked with red. Flesh tender, juicy, sweet and goor quality. Hardy. Productive. Ripens in July.

* BCDD. (Russian). Medium to large; light orange with blush on sunny side. Flesh sweet, juicy with flaror of the peach. Hardy and productive. Ripens in August.

\section{PLUMS}

Two years ago I harvested 580 bushels of plums from my two-acre orchard. Plums come into bearing early (often second year from planting.) The kinds listed here are the kinds I have tried and are the best for Eastern Nebraska. All are hardy and prolific.

\section{PRICES ON PICM TREES}

XX, 5 to $6 \mathrm{ft}$. tall, 2 yr. old, largest size.

Each Per 10

Extra select

$\$ 0.93$

4 to 5 ft. tall, 1 and 2 yr. old, Ideal size for farm

:3 to 4 ft. tall, 1 vr. old. Nice trees.

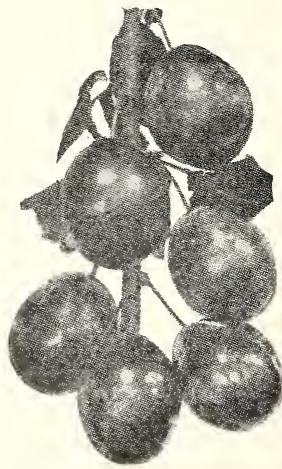

I will pay the freight, express or parcel post on nursery orders (but not seed) imounting to \$10.00 or over. This way you get free delivery. 


\section{PLUMS-Continued}

WILD GOOSE. Thin pink skin. Earliest to ripen. Juicy and sweet. Ripens in July.

* WYANT. Mottled red. Large size. Freestone. Good bearer. One of the best. Ripens in September.

DEsoto. Yellow Cling. Best canner. Very sweet. Hardy. Ripens in August.

STODDARD. Purple and red. Largest size. Good for market. Ripens in August.

* HANSKA. A Hansen hybrid. Largest size. Purple color. Small pit. Very hardy. Ripens in September.

* SAPA. Another Hansen hybrid. Bears second year. Purple color. Nearly Freestone. Ripens in August.

OPATA. Hansen hybrid. Olive green color. Freestone. Pleasant flavor. Ripens in September.

* Compass. This is a cherry plum. Small size. Wonderful bearer. Best for jelly. and canning. Ripens in August.

\section{PEARS}

Pears grow and bear wherever corn is grown. Canned for winter, they cannot be beaten for sauce. The hardiest and most prolific are the only ones offered.

\section{PRICES ON PEARS}

5 to 6 ft. tall, 2 yr. old extra select

Each Per 10

4 to 5 ft. tail, 2 yr. old standard...

$\$ 0.90$

3 to $4 \mathrm{ft}$. tall, 1 yr. old choice trees.

$\$ 8.50$

7.50

5.50

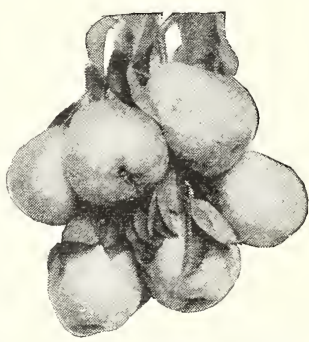

* KEIFFEr. Medium size. Beautiful yellow. Late keeper. Bears heavily. Hardy. Ripens in October.

* BARTLETT. Very large. Rich golden yellow. Finest flavor. Best early pear. Ripens in August.

DUCHEss. Largest size. Dull green color. Rich flavor. Bears second year. Ripens in September.

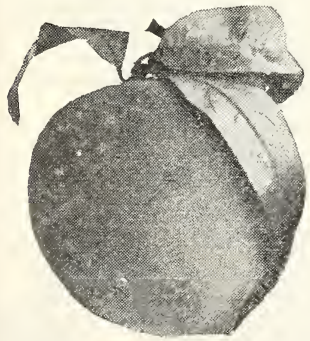

\section{PEACHES}

One of our best fruits. If planted in sheltered place will give splendid results. I offer only the hardiest and tested kinds.

\section{PRICES ON PEACHES}

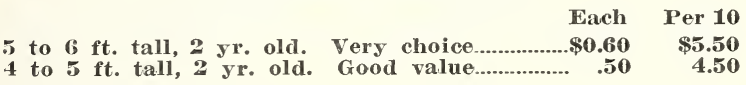

* BokAra. Large yellow. Red cheek. Best quality. Freestone. Very hardy. Ripens in August.

* ELBERTA. Largest size. Yellow splashed with red. High quality. Freestone. Hardy. Ripens in September.

NOTICE:-Salesmen for other nurseries, have told my customers that my nursery stock is shipped in from Missouri and other southern states, and that it is not hardy, and not adapted to this climate. I wish to state most emphatically that all my trees are grown here at Fremont and the varieties I offer are recommended by our State Horticultural Society, and my stock is all State Inspected.-J. A. YAGER. 


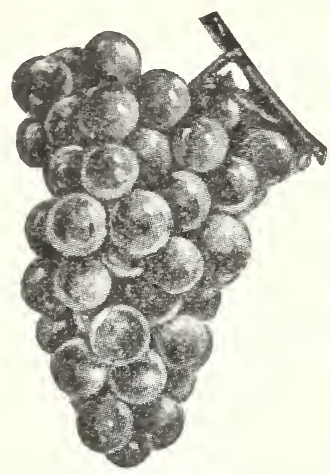

\section{GRAPES}

Whether you have a city lot or farm, you have a place for some grape vines.

This fruit comes into bearing quickly, requires little room, needs no special care, and will give splendid returns for many years to come.

No other fruit quite takes the place of the grape. Starred varieties are first choice.

\section{PRICES ON GRAPE VINES}

Each Per 10 Per

CONCORD, 2 yr. old, extra heavy.

100

CONCORD, 1 yr. old, good plants

.\$0.15 \$1.30

$\$ 10.00$

OTHER IKINDS, 2 yr. old, heavy........... $\quad .22 \quad \mathbf{2 . 0 0} \quad \mathbf{1 8 . 0 0}$

OTHER KINDS, 1 yr. old, fine plants... . $18 \quad 1.60 \quad 15.00$

* CONCORD. Blue black. The best old standby of all. Ripens in September. MOORE'S EARLY. Almost black. Fine flavor. Ripens in August.

* WORDEN. Purple. High quality. Juicy, sweet, free. Ripens in August.

ELVIRA. White. Very sweet. Hardy. Prolific. Ripens in September.

* BETA. Purple. Extra hardy. Medium size bunch. Ripens in September.

\section{Gooseberries and Currants}

These are too well known to need description. You cannot afford to do without these fruits. Both are hardy. Bear a year from planting and live for many years.

\section{PRICES ON GOOSEBERRIES AND CURRANTS \\ 2 year plants, large, rugged and thrifty.}

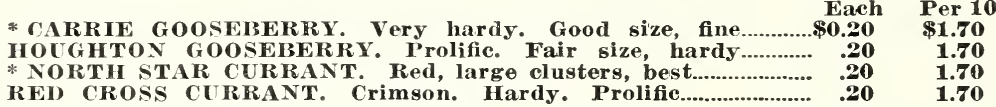

\section{Blackberries and Raspberries}

Whoever discovered (or invented) these fruits did a good job, for as a boy, a blackberry pie was just about the "whole show."

Both are hardy and give quick returns and fill a long felt want.

\section{PRICES ON BLACIKBERRIES A ND RASPBERRIES}

Any variety listed, good healthy plants: Per 10, 75e; per 25, $\$ 1.75$; per 100, \$5.00.

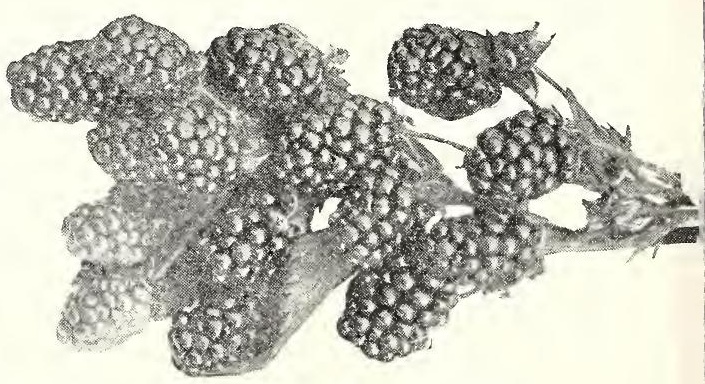

BLACK PEARL RASPBERRY. Jet black, compact cluster. Hardy.

* CUMBERIANI RASPBERRY. Purple. Largest size. Hardy. Early.

* ST. REGIS RASPIBERRY. Pink. Everbearing. Prolific. Hardy.

* SNYDER BLICIIBERRY. Black as tar. Very large. Best flavor.

Catalog concerns have been ridiculed because they sell at lower prices than others, but the truth is, that they save you money and are reliable or they could not exist. 


\section{Rhubarb and Asparagus}

Here are two plants you cannot afford to be without.

RHUBARB-VICTORIA. 2 yr. roots.

Best kind .............................................50 $93 \mathrm{c} \$ \$ 8.00$

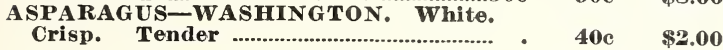

\section{Strawberries}

When you see your neighbor across the fence picking big red strawberries, you'll wish that you had a patch.

They are easily grown; require but small space and give great returns. The Everbearing kinds

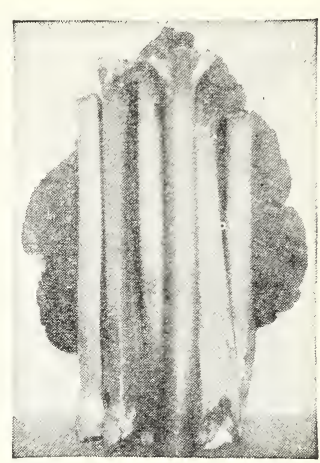

Victoria Rhubarb

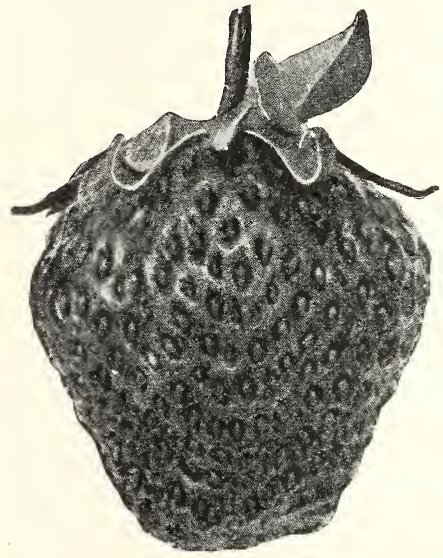

fruit the same year as planted. Other varieties the year following. Of course if you get the Progressive or Mastodon, you will have berries until freezing weather.

\section{PRICES ON EVERBEARING STRAWBERRIES}

Progressive Everbearing, postpaid-Per 25, 50c; per 100, \$1.40; per 1000, \$10.00. Mastodon Everbearing, postpaid-Per 25, 90c; per 50, \$1.60; per 100, \$2.75. Special prices on larger quantities.

- PROGRESSIVE EVERBEARING. This was the best all summer variety known until the MASTODON was discovered, but it is a good one yet and will give you a lot of fruit.

* THE FAMOUS MASTODON. This is an Everbearing strawberry. Will give you fruit from June until the snow flies. It is the largest strawberry yet introduced. The flavor and quality are the highest. Beautiful crimson color. Requires some attention as other varieties. Give it plenty of water and clean cultivation and you will be surprised. Get a start of these wonderful berries this Spring.

When you get your bundle of nursery stock do not look for your strawberry plants as they will be sent separately by parcel post, prepaid, and fresh from the field. 


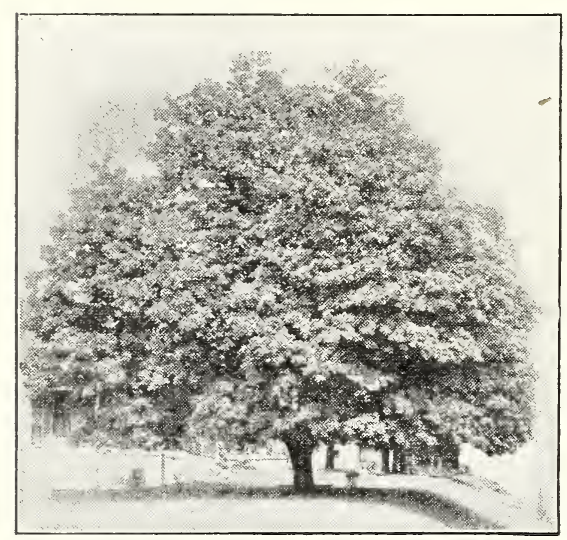

\section{SHADE TREES}

A tree is the silent friend of man. The landscape would truly be cheerless and desolate without trees. The humblest home can be sheltered at small expense as well as the palatial mansion, by the planting of trees.

A cottage by the roadside surrounded by trees and shrubs is the embodiment of our ideal of the most sacred place on earth-the home.

ASH, WHITE. Rapid growing tree of fine, symmetrical outline. A valuable street or park tree, and should be extensively planted.

MAPLE, SOFT. Everybody knows this fine native tree. A rapid grower. Very graceful and hardy. Splendid for street and shade trees. This tree transplants easily.

ELM, White. A splendid native. Easy to transplant. Very hardy. Gracefu] habit. One of the very best for lawn, street or shade tree.

\section{PRICES ON SHADE TREES}

ASH-Elm and Maple-5 to $6 \mathrm{ft}$.

Each Per 10

ASII-EIm and Maple-6 to $S$ feet

$\$ 0.75$

ASH-EIm and Maple-s to $10 \mathrm{ft}$.

1.00

$\$ 7.00$

$\mathbf{9 . 0 0}$

12.00

\section{FOREST TREE SEEDLINGS}

Every farmer should have a windbreak or shelter belt. You save feed for your live stock through winter by having them behind a grove, and the friendly shade in summer is of great value.

Start with some of my little forest trees and in a short time you will have a shelter, wood, poles and posts, besides adding 100 per cent to the looks of your farm.

\section{PRICES ON FOREST TREE SEEDLINGS}

Catalpa 12 to 18 inches tall

Per 100 Per 1000

Catalpa 18 to 24 inches tall

$\$ 1.00$

EIm 12 to 18 inches tall....

1.25

$\$ \mathbf{9 . 0 0}$

Elm 12 to 18 inches tall.

1.25

10.00

10.00

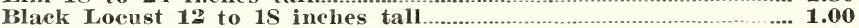

Black Locust 15 to $\mathbf{2 4}$ inches tall....................................................

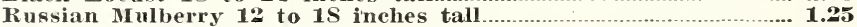

Russian Mulberry 18 to $\mathbf{2} 4$ inches tall............................................. 1.75

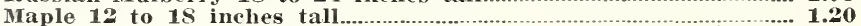

Maple 18 to $\mathbf{2 4}$ inches tall

1.60

16.00

9.00

10.00

10.00

15.00

10.00

15.00

Some say that Yager's trees are not good because they are too cheap. They are cheaper than others because I don't pay men 50c on the Dollar for selling them. I guarantee them first class and to be as good as any trees sold. 


\section{Catalpa Bungei}

\section{(Umbrella Tree)}

This tree is grafted six or eight feet from the ground; has a straight body, and forms a remarkable dense, round head that presents the appearance of a beautiful green umbrella. Most desirable for lawn or street effect. This tree is hardy and dependable.

\section{PRICES ON CATALPA BUNGEI}

\section{6 to 7 ft. stems, 2 year heads.. 5 to 6 ft. stems, 2 year heads.}

You may have a home of stately proportions, or it may be only a modest cottage, but the picture

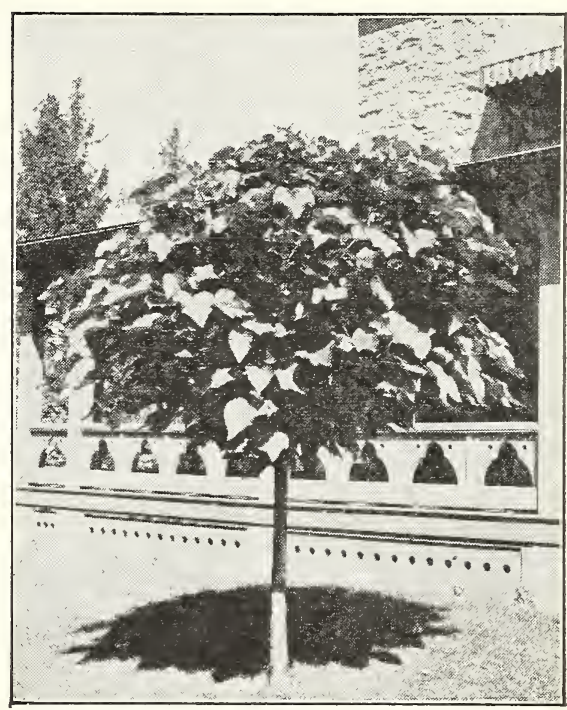

Catalpa Bungei

is not complete unless you have an assortment of shrubs. The diversity of foliage and bloom extending from May until Winter is such as to afford a succession of cheer and beauty throughout the growing season.

No better investment can be made than in a few hardy flowering shrubs. My list comprises the hardiest and best bloomers for this latitude.

* SPIREA. (Bridal Wreath). The best Spirea of all. Perfectly hardy. An annual bloomer, producing a wealth of white flowers. A good grower and makes a beautiful hedge.

* BARBERRY THUNBERGII. (Japanese.) A great acquisition for hedges or specimens. Will thrive anywhere. Handsome foliage, green and copper colored, but turning to orange and red in the fall. Scarlet berries line the branches all winter.

* SNOWBALL. The old favorite. Hardy and free bloomer. Pure white blossoms in June. Blooms young and is very desirable.

* HYDRA NGEA. (Paniculata). The best of the late flowering shrubs. Very hardy. A free bloomer. Produces immense clusters of creamy white flowers. Blooms the first year from planting. One of the best.

* MOCK ORANGE. (Syringa). A very hardy upright shrub. Large white sweet scented blossoms appear in May or June. The finest perfume of the garden.

* BUTTERFL BUSH. (Buddleia Magnifica). The latest thing in gorgeous shrubs. Grows four feet tall. Has great clusters of lilac colored flowers. Very fragrant. Attracts large numbers of butterflies-hence its name. Exceedingly attractive.

PRICES ON ORNAMENTAL SHRUBS

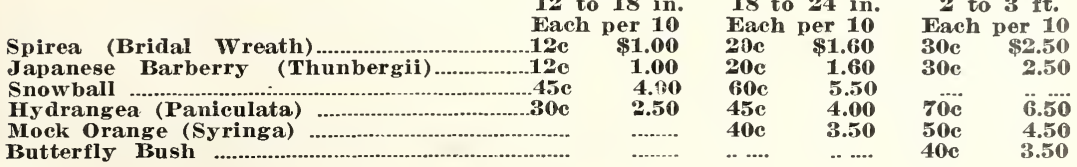




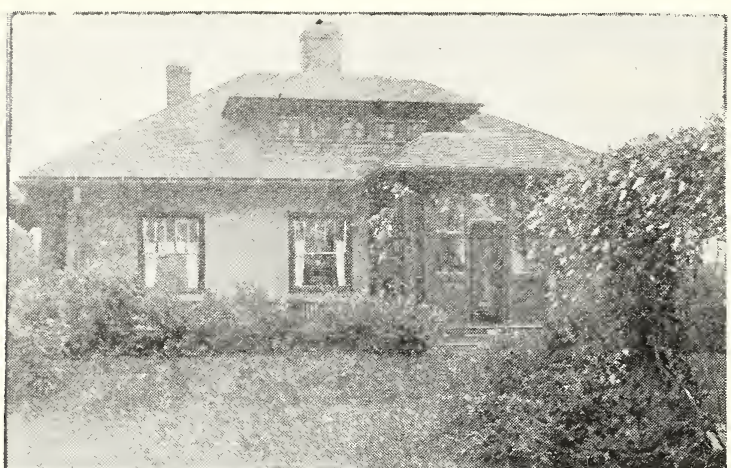

Wisteria.

teria with its wealth of purple is a benediction. shade and a riot of autumn hued foliage.

\section{Hardy Vines}

There is nothing more attractive than a vine in bloom by the porch or trellis. Vines may be used to cover fences, or to hide some unsightly object. $\mathrm{Noth}$ ing is more pleasing than the fragrance and beauty of the Paniculata Clematis. The Honeysuckles are most attractive, also. The WisThe Woodbine affords

\section{PRICES ON HARDY VINES, Two Year OId.}

Jackmanni Clematis, large purple flower.

Each $\$ 0.90$

Paniculata Clematis, best. White scented bloom. .50

Scarlet Trumpet Honeysuckle, clusters of scarlet flowers........................... .30

Wisteria, purple and lavender bloom in profusion............................................ .50

CLEMATIS, Purple (Jackmanni). The queen of all vines for size and richness of flowers, which are violet purple, 3 to 4 inches in diameter. Needs winter cover.

CLEMATIS, White (Paniculata). The best hardy white Clematis. Vigorous, sweet scented pure white flowers. Blooms late in summer.

HONEYSUCKLE (Scarlet Trumpet). A good hardy climber. Free bloomer. Flowers the shape of a trumpet. Fine for a trellis.

AMPELOPSIS, (Engelmanni). A new hardy woodbine. Better than Boston Ivy. Good thick foliage. Splendid for clinging to walls of all kinds. Will grow any where. The best vine.

WISTERIA (Purple). A rapid hardy growing vine. Produces large drooping purple clusters of flowers in May and June.

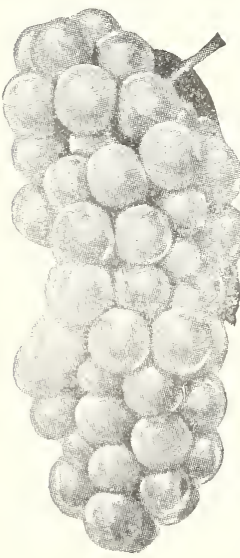

\section{FREE OFFER}

Good Until March 25, 1929.

Send me an order for nursery stock (not seed) for $\$ 8.00$ or more, before above date, and I will send you 5 plants FREE.

Five NIAGARA GRAPE VINES. The best WHITE grape. Large clusters. Very hardy. Fruit sweet and delightful. Aromatic and productive. 


\section{HARDY ROSES}

CLIMBERS 2 years old.

Crimson Rambler, rich crimson red, best climber.

Dorothy Perkins, shell pink. Hardy. Flowers borne in clusters.

Seven Sisters. rose red. Good climber. Hardy. Very showy.

\section{BUSH ROSES, H. P. 2 years old.}

Frau Karl Druschki, White American Beauty. Double Fragrant.

Paul Neyron, bright pink. Fragrant. Largest size grown.

Gen. Jacqueminot, bright red. Hardy. Fragrant. First

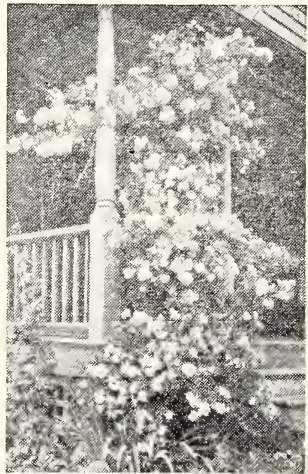
choice.

Prince Camille de Rohan, darkest red. Sweet. Double. Fine.

Madam Plantier, pure white. Good for cemetery. Good bloomer.

Magna Charta, shell pink. Very fragrant. Strong grower.

Prices on Roses are 50c each or $\$ 4.50$ per 10 .

(THE BEST SIX ROSES GROWN).

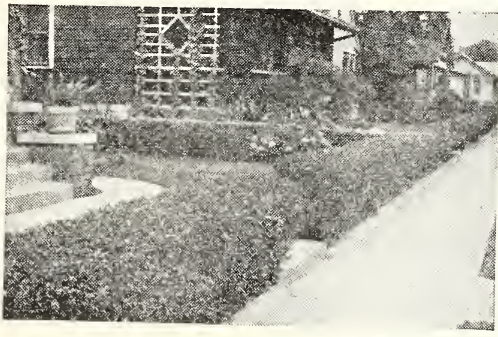

Privet Hedge

\section{Ornamental Hedges}

In landscape work, and yard decorations, hedges are being planted more than formerly. As a division line, a hedge is most desirable, or it may be placed on either side of a drive with splendid effect. As an outer enclosure, it is very attractive.

The three kinds offered here are the best for this latitude. The Privet and Spirea may be sheared to the desired height, thereby producing a formal
its beauty. The Barberry should be allowed to grow naturally, thus preserving a beauty.

AMOOR PRIVET. Extremely hardy. Has no thorns. Dark glossy green foliage. Makes a dense growth. May be sheared to produce pleasing effect. Very at-
tractive.

SPIREA VAN HOUTEII. Often called Bridal Wreath. Very hardy. Long delicate branches covered with beautiful white flowers in June. Makes a splendid hedge. where. Grows two or three feet tall. Branches called Japanese Barberry. Hardy any followed by small red berries that. Branches covered with handsome little flowers,

\section{PRICES ON ORNAIMENTAL HEDGES.}

Amoor Privet (very hardy) 12 to 18 inches tall

Per 100

Amoor Privet (very hardy) 18 to 24 inches tall

88.00

Amoor Privet (very hardy) 18 to

Spirea Van Houtei

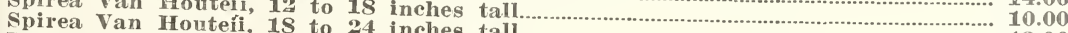

Barberry Thunber,

Barberry Thunbergii, 18 to 18 inches tall .......................................................................... 10.00

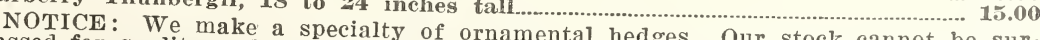
passed for quality and our prices are the sure and plant one of our hedges this Spring. 


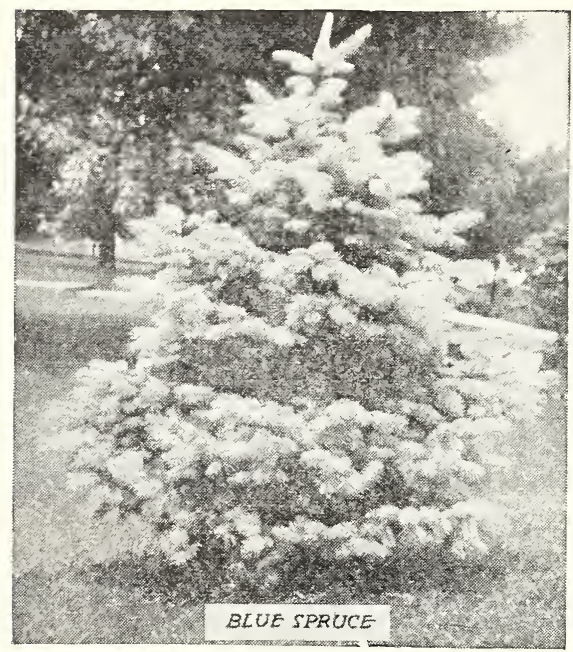

\section{EVERGREENS}

Nothing is more attractive in the winter than some evergreen trees about your home. They are a source of pleasure in the winter months when all other vegetation is withered and brown.

I have a splendid supply of these trees both as individual specimens, for ornamental planting, as well as for shelter belt and wind break. My list is so long that I cannot quote them to you here but will be pleased to give you the prices on any you may be interested in.

\section{Hardy Perennial Plants}

There is no class of plants more desirable than these. They are better than the annuals because you plant them but once, and each spring they come forth with renewed vigor to gladden the heart and embellish the landscape. The plants listed here are all hardy, and afford a profusion of bloom throughout the season.

RLEEDING HEART. A great favorite. Curious heart-shaped blossom. Fine for border or as a single plant. Blossom light red. Very hardy. Blooms in April and May.

GOLDEN GLOW. A fine hardy plant. Good for background. Very hardy. Flaming yellow, double flowers. Blooms in August and September.

PHLOX. (Hardy). The most charming flowers. Blooming from June till November. Flowers range from pure white to darkest crimson. Plant in groups. Three colors: red, white and pink.

YUCCA. (Adam's Needle). Stalks grow four to six feet tall. Are covered with large, bell-shaped flowers. Foliage green the entire year. Extremely hardy and conspicuous.

PRICES ON HARDY PERENNIAL PLANTS

Phlox (best assorted colors) ............................................................................\$0.1S

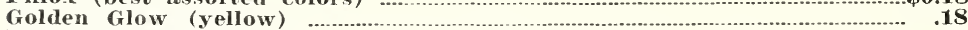

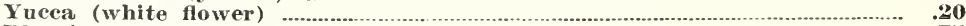

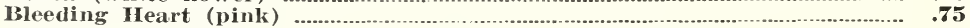

Per 10

$\$ 1.60$

1.60

1.75

7.00

I want to call your particular attention to our ornamental hedges, shown on page 11. See our low prices, and best quality is guaranteed.

November 16, 1928.

I never had any trees that did as well as the forty Delicious apples that I got from you last Spring, and it surely wasn't a really favorable season, but they all grew anyway.

G. A. CLAUSen, Mead, Neb. 


\section{PAEONIES}

These flowers stand in a class by themselves, being entirely hardy, having no insect enemies, and never failing to produce an abundance of fragrant blooms each year.

Next to the Rose, the Paeony is the grandest flower under cultivation. They never fail you. The finest Decoration Day bloom.

The following kinds are the very choicest of the hundreds of known varieties. Order by number.

\section{PRICES ON PAEONIES}

Any variety listed (strong plants) each 50c; 10, \$4.00

No. 1-Duchess De NeMours. The largest white Paeony of all. Very double. Has a delicate fragrance. Flower ofter four inches in diameter.

No. 2-F. Ortegat. Large crimson bloom. Very double. Bewitching perfume. Buds resembling the rose. Long stems.

No. 3-Floral Treasure. Great pink flowers. Free bloomer. Very double and sweet perfume. A fine cut flower.

No. 4-LMartine. Double pink bloom. Peach blossom color. Slender stems. Moss rose fragrance. Early bloomer.

No. 5-Louis Van Houtte. Dazzling red. Rose shape. Medium size flower. Very double. Apple blossom odor. Blooms in midseason.

No. 6-Officinalis Rubra. Dark rich crimson. Semi-double. Golden center. Always in bloom for Decoration Day. Very earliest.

\section{Send For Your Seed Samples at Once}

As we can save you money on early orders.

If you order now, we will hold your order for you until March First, if you wish.

Look my catalog o yer carefully and make your selection of nursery stock now while stock is complete, as early orders receive the preference. 


\section{YAGER NURSERY and SEED CO., FREMONT, NEBRASKA}

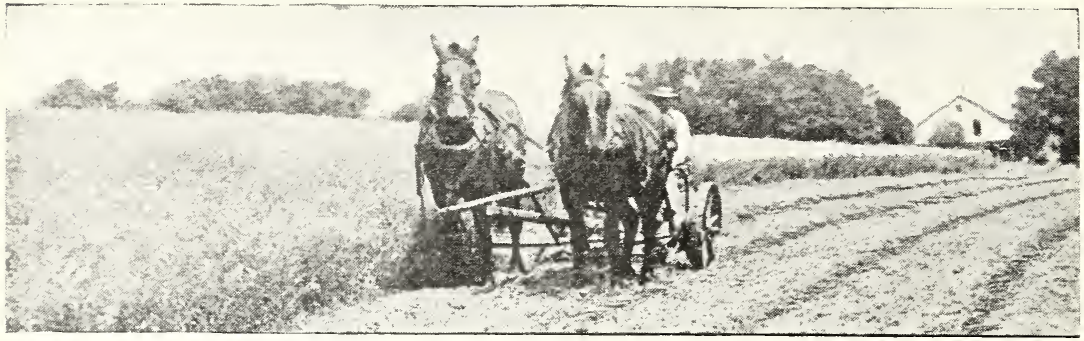

\section{FARM SEED}

Farm seed is not a luxury. You cannot reap unless you sow. The success or failure of agriculture is based largely on the quality and purity of the seed you sow, and if Nature is kind to us, we will have bountiful crops provided we sow good seed.

Most of my Farm Seed is bought direct from the grower, and we use our best efforts, after many years' experience in selecting seed of high germination and good purity.

Nearly all the seed I buy is carefully cleaned by us so as to eliminate all weed seed, after which it is tested for germination and purity, and we try to comply with our state law in this respect.

A short time ago, I attended a farmer's convention in which the chief topic of discussion was the manner in which the yield of crops could be increased. Charts were shown in which the average yield of our crops in Nebraska was very low. Charts were also shown giving high yields of corn, wheat, oats and ordinary farm crops. The whole question revolved around the fertility of our soil.

The men who were getting big yields were invariably those who had rotated their crops and used some of the legumes such as Alfalfa, Red Clover and Sweet Clover in their rotation plan.

Two farmers separated only by a barbed wire fence, with similar soil, were shown to have produced 32 bushels of corn and 63 bushels of corn, respectively. The difference was not far to seek. The man with the larger yield had sown freely of the clovers in the years preceding.

But it is useless for me to preach to you farmers on the benefit of maintaining the fertility of your soil. Those of you who have tried it know its advantages. Those of you who have not will still maintain that farming does not pay. You will say that I am selfish in making these statements, because I have seed to sell, but whether you fertilize your land with seed from me or from someone else, you yourself know, that it pays, and pays big dividends.

By all means, you ought to spray your fruit trees. That is the way to get fine fruit. Iill the bugs, worms and insects, and you will have better quality of fruit than is shipped in from the Western states. The cost is small and it does not take much time. 


\section{Some Remarks by Mr. Yager}

I have no broadcasting station, and could not get the assignment of a wave length now if I laid $\$ 100,000.00$ down in cash on Uncle Sam's table. So there is only one thing I can do to tell you my story about seed and trees and that is to send you my little catalog.

When you get this little book, you may be disappointed that there are not a lot of colored pictures, a bigger catalog and a more expensive lay-out. But I have decided to give you a less expensive catalog, so that I could make you better prices on the things I have to offer.

Beautiful colored pictures do not produce larger crops, but good seed at reasonable prices will turn the trick.

I have made every possible effort to offer you good seed and nursery stock at the lowest possible price with but a small margin for myself.

You will find every page in this book quotes real honest-to-goodness values.

I get hundreds of letters every year from former satisfied customers, and from many new ones who are joining our large family.

\section{J. A. YAGER.}

\section{My Terms}

PRICES. The prices quoted here are for seed delivered at depot or Express office at Fremont, Nebraska. You are to pay the Freight or Express charges. Terms, strictly cash.

SACKS. I make no extra charge for sacks. The sacks are "weighed in" as seed. Great care is taken to have good strong sacks, and in most cases I double sack the seed to avoid leakage.

GUARANTEE. I guarantee all seed shipped to you, to reach you in good condition. If sacks are torn or seed damaged, require the $\mathbb{R}$. $R$. or Express Agent to note same on your freight or express receipt. Then notify me.

APPROVAL. When you get your shipments of seeds from me, if they are not as represented, write me about it, and $I$ will adjust the matter satisfactorily with you. I will do everything possible to please you.

DISCLAIMER. We give no warranty, express or implied as to description, quality, productiveness or any other matter of any seeds we send out and we will not be in any way responsible for the crop. If the purchaser does not accept the goods on these terms, he must notify us at once, and we will give instructions for disposition of goods.-J.A. YAGER.

FREE SAMPLES. Ask for free samples of seed. I like to have you see just what you are buying, and the seed I send will be exactly like the sample you get.

SUBJECT TO SALE. I have a large supply of seed on hand, bought right and all good stuff, and the prices I make you now are only good till the present supply is exhausted.-J. A. YAGER.

QUANTITY. On all mail orders, I do not care to fill any orders for seed for less than $\$ 1.00$, as cost of handling smaller orders is excessive.

WEIGHTS PER BUSHEL AND POUNDS PER ACRE

\begin{tabular}{|c|c|}
\hline Lbs. Per B & $\begin{array}{l}\text { Sow Per Ac } \\
12 \text { to } 15 \text { il }\end{array}$ \\
\hline Red Clover & 10 to 12 ll \\
\hline Alsike Clover ........60 & 6 to \\
\hline weet Clover ...........60 & 15 \\
\hline ite Clover ........60 & to \\
\hline 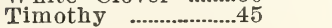 & 15 \\
\hline
\end{tabular}

\begin{tabular}{|c|c|}
\hline Lbs. Per Bu. & $\begin{array}{l}\text { Sow Per } \mathbf{A} \\
8 \text { to } 10\end{array}$ \\
\hline In Grass .....40 & 18 to 221 \\
\hline en Millet .......50 & 35 to 50 \\
\hline er Cane & to 100 \\
\hline Grass $(\mathrm{Ky}.) \ldots 1$ & 30 to 50 \\
\hline
\end{tabular}




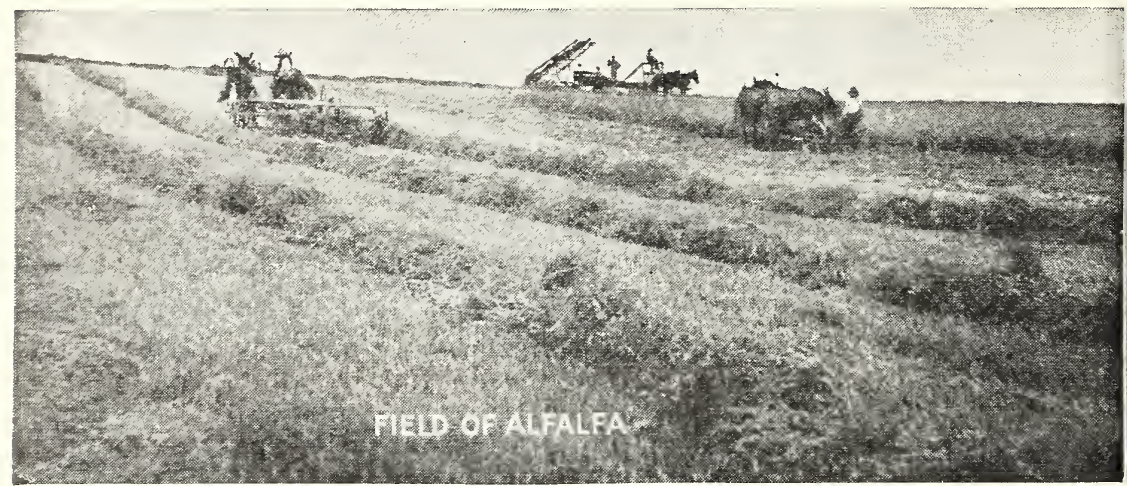

\section{ALFALFA}

You will find a field of Alfalfa on every successful farmer's land, as it is the permanent mainstay for hay and pasture.

Of course you can squeeze through with Sudan Grass, Cane, Millet or Wheat straw with your live stock but nothing takes the place of Alfalfa.

The cost of seeding an acre is not great if you use good hardy seed; your field is good for many years and you are nearly sure of three good cuttings per season. No horse or cow should look his owner in the face and ask him where his alfalfa hay is.

The dairyman cannot do without alfalfa. Milk and butterfat are what he is after. Alfalfa helps make up the balanced ration.

Other crops following alfalfa will show a marked increase in yield. If you happen to have too much alfalfa hay your less thrifty neighbor will be glad to buy it from you at a good price.

But I could go on talking to you and fill many pages on the advisability of growing a field of alfalfa, but that is not necessary. Everybody admits it. Therefore my story is about ended.

By the way, I must tell you about my "BEE HIVE" Alfalfa seed. "When you get alfalfa seed, you should know where it is grown, and be sure that it is of hardy origin.

Now the "BEE HIVE" Alfalfa is grown in Utah by 2200 members of the "BEE HIVE" Growers' Association.

This seed is grown a mile above sea level. Winter temperatures are often 25 to 30 degrees below zero. Anything that can stand that temperature is certainly very hardy.

The "BEE HIVE" seed comes only in one bushel sealed bags, and the origin is absolutely guaranteed to you.

If you want something that is perfectly hardy and that will stand the blistering heat of summer and the Arctic blasts of winter, sow a patch of "BEE HIVE". Sow 12 to $15 \mathrm{lbs}$. per acre. (See prices on colored sheet.)

Great care is used in packing the nursery stock $I$ send out, so that it will grow, and you should take good care of it when received. Plant it at ONCE, so it will suffer no exposure. 


\section{RED CLOVER}

All my Red Clover seed (and I have a lot of it), was raised within 30 or 40 miles of Fremont. Every grain of it is "Home Grown." All of it has been recleaned and it contains no noxious weeds so far as I know, and I give you the test on every bag you buy of me.

\section{In buying I refused a good many} lots because they contained noxious

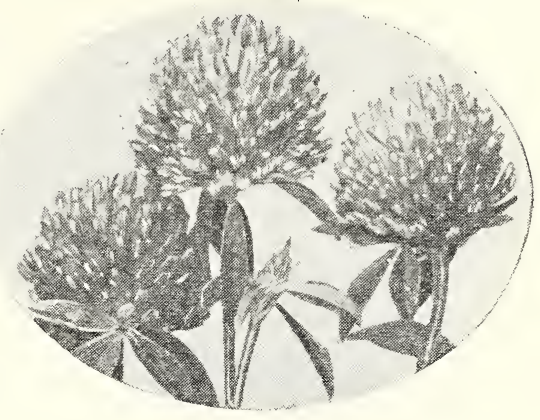
weeds, so be sure that you get good clean seed to sow.

When you plow and dig and scratch and sweat to raise a crop of corn and it only makes you 28 to 30 bushels per acre, you know at shelling time that there is something wrong with your land. There is a substance in the soil known as nitrogen. It is created by decayed vegetation, and is the essential element for the fertilization of the soil. Whenever this element is lacking, the result is poor crops, and one of the best ways of restoring it is to sow Red Clover.

Men who sow Red Clover are the successful farmers in your neighborhood. They have red barns, white houses, and blue automobiles and pay their notes promptly at the bank. The fellow that does not sow it is liable to be a little "hard up" and he says that farming is "tough sledding."

Just ask your county agent about Red Clover. Read what the farm papers say about it. There is no argument about Red Clover being a good thing for your land.

If you haven't already procured your seed, get my free samples, or come in and see me and we will talk it over, as I certainly can fix you out on quality as well as price, as my overhead is small, and my margin of profit not very big.

Sow 10 or 12 lbs. per acre. (See colored sheet for prices.)

The man that sows Red Clover seed is making a good investment. It is about as safe as a first mortgage on land, only the returns are often much larger. If you want 70 bushels of corn per acre in the future, sow Red Clover.

You hear a lot of talk about inoculating your seed, such as Alfalfa and Sweet Clover. Many do not know what this is done for; but, plainly speaking, it is done for the purpose of restoring to your soil, some of the elements that are lacking. Scientific men in Agricultural Colleges have evolved a product known as MeQueen's Inoculator and if applied to the seed that you sow, it will promote the growth and vigor of the plant, and take the nitrogen from the air and fix it in the soil in the shape of nodules on your plant. You will make no mistake in using McQueen's on fields that have not been inoculated before. I can put my unqualified endorsement on McQueen's, and will be mighty glad to furnish it to you. See prices on back of order sheet. 


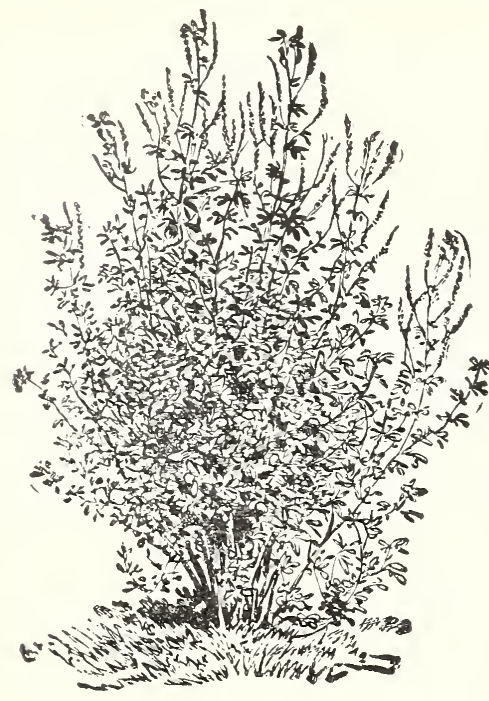

\section{SWEET CLOVER}

I have secured several carloads of White and Yellow Sweet Clover seed for my customers. Part of this seed was grown in the Dakotas and some was grown here locally.

Most of this seed is scarified. (P. S. This is a big word for "scratched"). It is free from noxious weeds and has good germination and purity.

The Yellow should be sown for pasture and hay. About $90 \%$ of the farmers sow the White Blossom because of its more vigorous growth and as a stronger fertilizer.

A few years ago, a good German neighbor nearly chased me off from his place when I advised him to sow it on his poorest land. He said it was an awful bad weed, and if it got started, he couldn't get "rade" of it. Well he has since been converted and now raises big

crops following Sweet Clover.

My sales on Sweet Clover are increasing every year, and my farmer friends must be obtaining good results or they would not come back for more, because you can't fool a farmer as he knows where the goose is that laid the golden egg.

Farmers around here that have been carrying their stock cattle through the winter behind a barbed wire fence and feeding them dried corn stalks, claim now that their cattle stand up to the rack and get "hog fat" eating Sweet Clover hay in the winter, and that's no dream. I've been out and seen it myself.

One good thing this year, this seed is cheap, as you can get about three bushels of Sweet Clover for the price of one bushel of Red. Now, mind you, I do not say that Red is not good, but I do say that Sweet Clover is one of our best fertilizers, hay and pasture crops.

Some Professor at Lincoln said that a crop of Sweet Clover on an acre was equal to 20 loads of barnyard manure. Well I guess he was a little high, but it sure does the business for your land.

People on the hills or upland seem to have more trouble getting a good stand of Sweet Clover the first year, but if you will sow it where you have had alfalfa previously, you are nearly sure of getting a good stand, or you might try some of the advertised inoculators, but if you don't want to spend your money that way, you can mix some of the soil from an old Sweet Clover field with your seed and that will turn the trick.

I never know when to stop talking about Sweet Clover because I have observed so much of the benefit derived from its use.

Sow 12 to $15 \mathrm{lbs}$. per acre. (See colored sheet for prices.) 


\section{Alsike Clover}

Alsike Clover is good for pasture, and will last longer than Red Clover. It also makes fine hay and improves your soil.

Alsike is rather partial to wet soil, but will grow pretty well wherever you put it. If you sow it for hay purposes, you should sow a little timothy with it to hold it up when you cut it, and it will cure better this way.

A bushel will sow about ten acres, and should have a light nurse crop the first year.

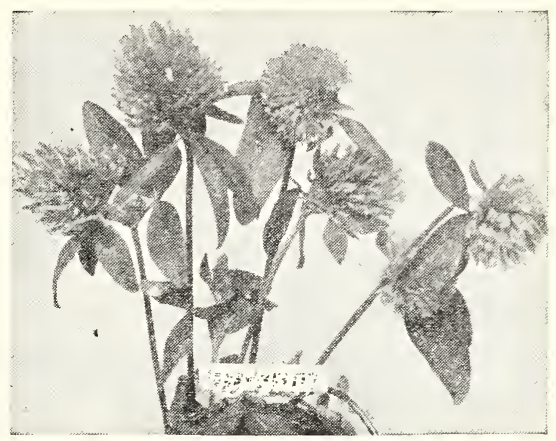

Asikle Clover

Some people call it "Swedish Clover." It seems to be a cross between the White Dutch and Red Clover and some think it is a Hybrid.

Most farmers think that stock will not bloat on Alsike as much as on Red Clover.

This seed is very scarce this year and the price is rather high, but a bushel, as I said, goes a long ways. It seldom ever winter kills and will reseed itself indefinitely.

Sow 6 to 8 lbs. per acre. (See colored sheet).

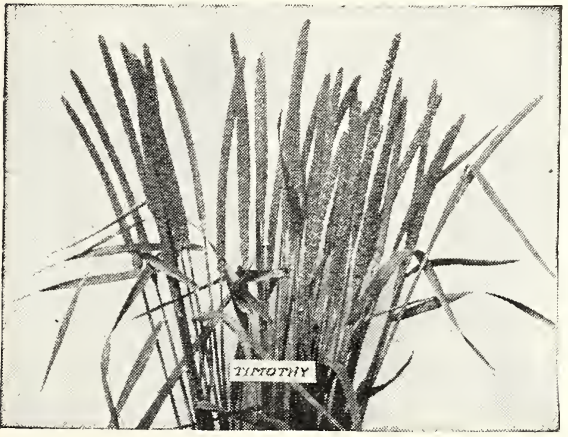

Timothy

Timothy is one of our best known hay and pasture crops. It will do well wherever corn can be raised. Many farmers grow it as an exclusive crop of hay for feeding horses, and it is superior for this purpose, but to get the best results from it for hay, you must cut it before it is too ripe, otherwise you would sacrifice its feeding value.

If you have a piece of land that has a tendency to "wash" use timothy, as the stiff sod will prevent erosion. Of course timothy is not a soil builder like the clovers, but it is mighty nice in the winter to go up into your red barn and fill the mangers with nice, bright Timothy hay. It hardens up the flesh of the horses for spring work.

As a pasture crop it sure is a dandy. When I used to turn my herd of Jersey cows on my patch of Timothy in the spring, it certainly was a pleasure to stand and watch them, and then the great quantity of yellow milk at night told the story.

The seed may be sown in the spring or early fall, but you do not get a great deal of hay for feed from it, the first season it is sown. But after that you have got a permanent field for many years.

Sow about 15 lbs. per acre, with a light nurse crop. You can hardly sow it tro earlv-as it will not be iniured by late frost.

(See colored sheet for prices). 


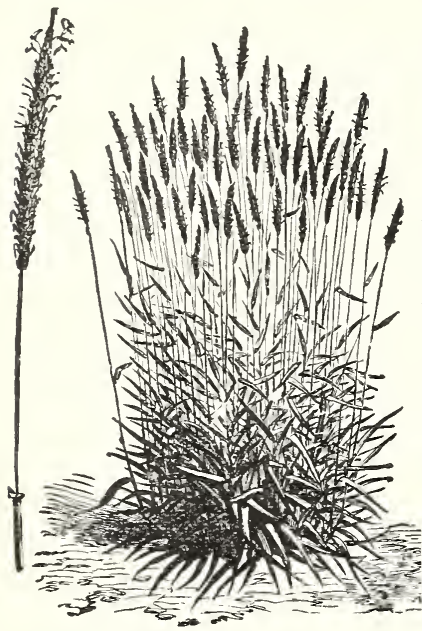

\section{Timothy and Alsike Mixed}

I have found that a lot of farmers like this mixture for a pasture crop, as both of these seeds are entirely hardy and will never winter kill, and the period for pasturing this mixture is longer than where either is sown alone.

You will seldom if ever be troubled with your stock bloating from this combination, and if you have more than you can pasture, you can get some mighty fine hay for winter use from this mixture.

This seed is comparatively cheap. Your meadow will stand a lot of rough usage, and your pasture will be there until you put your olough in and turn it over, and remember that

The seed we offer this year is $20 \%$ or more Alsike and weighs $45 \mathrm{lbs}$. to the bushel. As I said before, this mixture is very popular with the farmers. Sow about $15 \mathrm{lbs}$. per acre. (See colored sheet for prices).

\section{Rape \\ Dwarf Essex}

Farmers who raise hogs extensively, place a high value on Rape, as it is a good conditioner, and mighty healthful for your pigs.

If you want to see a pleasing sight, just put some pigs, calves or lambs on a patch of Rape and see what happens. They sure go after it strong, as it makes bone and muscle.

You can sow Rape over a long period, even up to the time you lay by your corn, but don't sow it too early. Rape is a one-year crop and will be dandy good feed up until the first heavy frost comes, and it is pretty good for your soil too.

Sow about 8 to $10 \mathrm{lbs}$. per acre. (See colored sheet for prices).

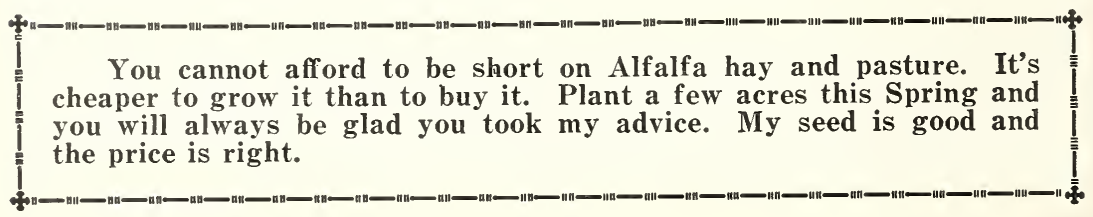




\section{GERMAN MILLET}

Yes, they made us call it Golden Millet following the Great War, but now we call it by its right name.

Well, most farmers know all about Millet. I think the German is the best, and you'd be surprised at how many farmers there are that sow it yet.

One advantage is that it may be sown late in the season, where other crops have been hailed out or drowned out or lost from any other cause.

It makes good feed for cows and calves if cut at the right time, but most farmers do not like it as hay for horses.

When you cut it, be sure and cut it before the seed matures or it will have lost most of its strength.

If you leave it for seed, it makes a good yield and you can usually find a market for it among your neighbors or some seed house.

You should sow three-fourths to one bushel per acre broadcast. Of course it takes less when drilled. (See colored sheet for prices).

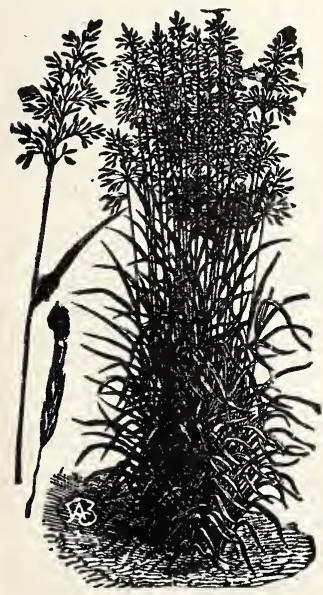

\section{Bromus Inermis}

This grass is often called Brome Grass. If you want a good grass that will stand up under almost all conditions of excessive moisture, drought, heat and cold, just try Brome Grass.

It will produce a good crop of hay on land that is too poor for Clover and Timothy. If nay be sown with winter wheat or early in the Spring.

Many farmers mix a little Red Clover with it when sowing it for pasture. The call for this seed is increasing every year.

Sow 20 to $30 \mathrm{lbs}$. per acre if sown alone. This grass is a perennial and will remain for you many years after seeding. (See colored sheet for prices).

Believe it or not. Sweet Clover puts the pep in your soil. Subsequent crops prove it. It fills your hay mow; it delights your cow; it renews your soil; adds to your bank account, and all is well. 


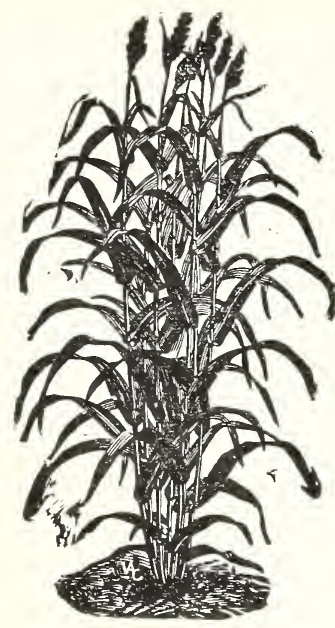

\section{Amber Cane (Sorghum)}

If you want to raise several tons of nutritious feed per acre, sow Amber Cane. It will do to fill in with when you are short of Alfalfa, Red Clover and Sweet Clover hay.

If you do not let it get too coarse before you cut it, it makes you a good grade of roughage. It is not unusual to get from five to eight tons per acre.

Mules, horses and cattle keep in fine winter condition on well cured Cane.

Do not sow your seed too early. If you do it will rot as it is strictly a hot weather plant.

If you sow heavily, the stems will be small; it will be more easily cured and the foliage more abundant. So you will get better feed and less waste.

Sow late in the spring at the rate of $1 \frac{1}{2}$ to 2 bushels per acre. (See colored sheet for prices.)

\section{Sudan Grass}

And now we come to this wonderful annual forage plant which is being so universally used in all parts of the country.

You can take more pounds of milk and butter out of an acre of Sudan hay or pasture than anything. I know of. You see you get two good cuttings each summer from Sudan and then you have some good fall pasture left until frost comes.

Iany farmers cut this hay with binders and shock it up for curing. Much of the Sudan seed grown in Eastern Nebraska does not mature well, and has a low germination.

All kinds of stock devour Sudan hay greedily in Winter and come out sleek and fat in the spring.

Failure with this crop frequently results from being sown too early. Do not sow this seed until late, or until the ground is thoroughly warm.

Sुow $20 \mathrm{lbs}$. per acre. There are $40 \mathrm{lbs}$. to a bushel. (See colored sheet for prices).

\section{White Clover (for Lawns)}

This is sometimes called the White Dutch clover, and is the well known kind seen growing in pastures and on our lawns. For pasture, in combination with Bhue Grass or Alsike this clover is very desirable.

\section{Kentucky Blue Grass}

This plant is too well known to need a description. It is the kind we use on our lawns and is found growing in our tame mearlows often being sown with White Clover. The plant is extremely hardy and endures armost all conditions of climate and weather.

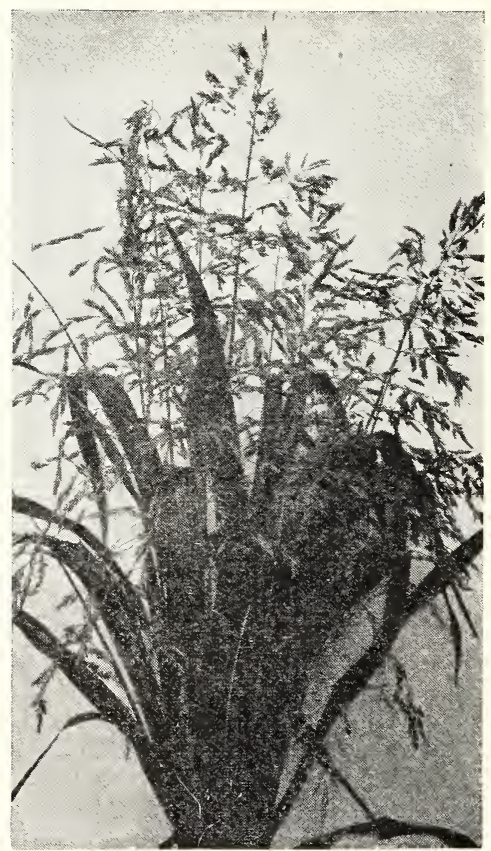

Sudan Grass 
PLEASE CSE THIS SHEET IN ORDERING STOCK

NURSERY AND SEED ORDER SHEET

\section{YAGER NURSERY and SEED CO.} FREMONT, NEBRASKA

DATE

Gentlemen: Please send me the following stock:

Name

Postoffice

R. F. D.

County State.

Ship to

(Name of R. R. Town)

Ship by

(State whether by express, freight or mail)

\begin{tabular}{|r|}
\hline \multicolumn{2}{|c|}{ AMOUNT FNCLOSED } \\
P. O. Order... \\
Exp. Order.... \\
Bank Draft ... \\
Cash ................ \\
Check ....... \\
Total....
\end{tabular}

Quantity


ORDER SHEET

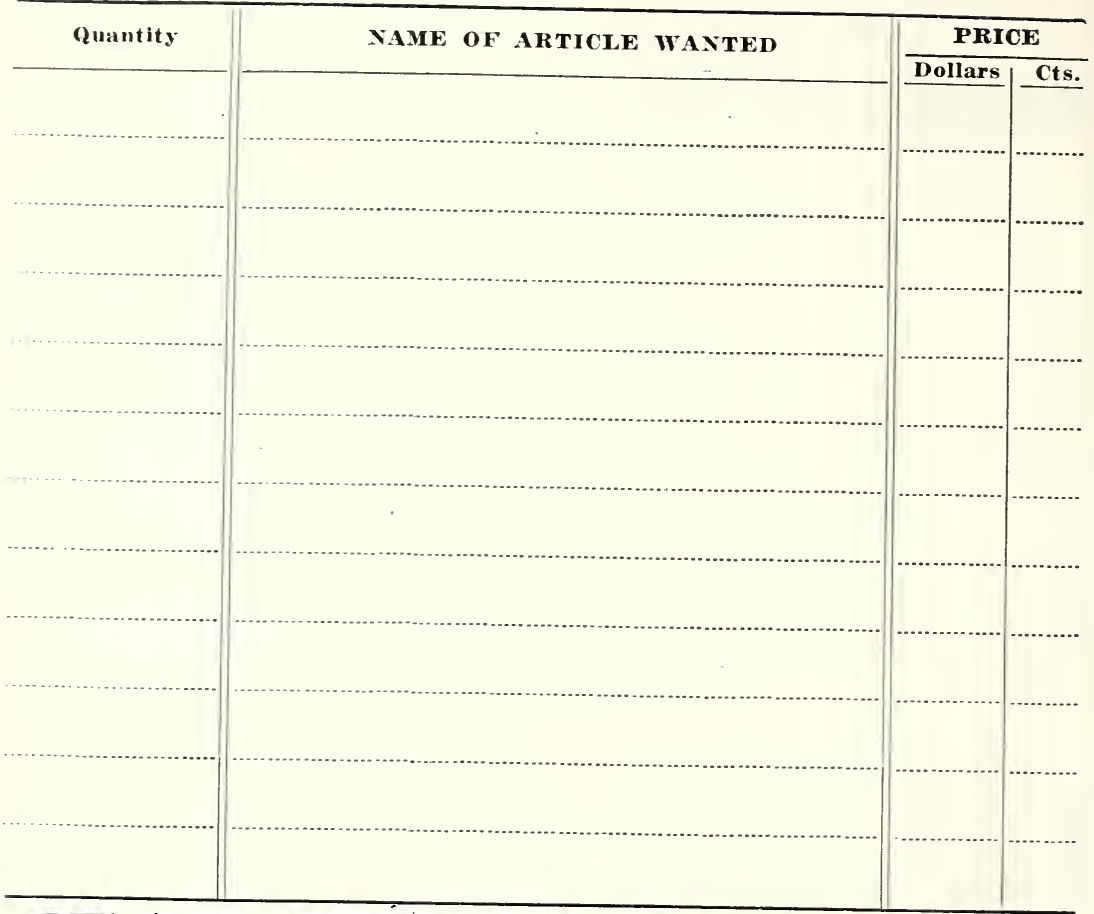

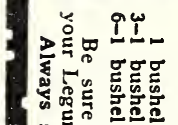

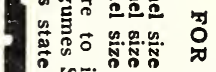

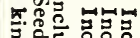

司的

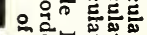

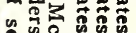

ज़ी की

ล.

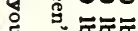

心 苛它

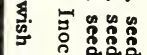

- E مa

ज.

弯

ڤ in้ํㅇㅇㅇ $>$

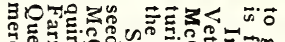

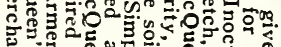

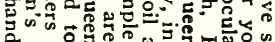
ग

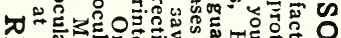

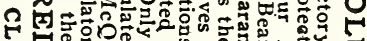

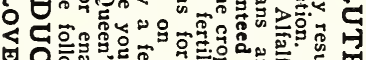

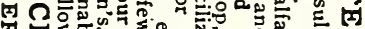

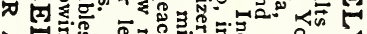

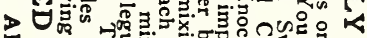
Z 包 品

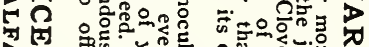

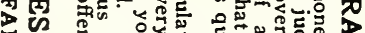

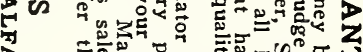

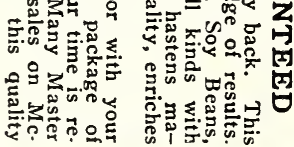

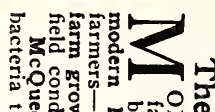

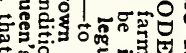

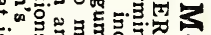

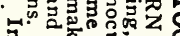

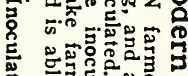
क्ष

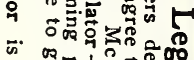
₹ $\rightarrow$ 政事

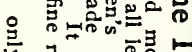

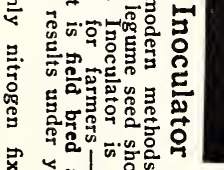

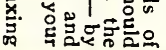


You certainly ought to plant some Delicious apple trees this Spring. These trees are hardy. They bear well, and early, and the fruit is unequalled for quality. See prices on page - and picture on front cover.

\section{INDEX}

Nursery Department

Page

Apples

Apricots

Asparagus

Blackberries

Catalpa Bungei

Cherries

Crab Apples

Currants

Evergreens

Forest Seediings

Gooseberries

Free Offer

Grapes

Hedges ...
Paeonies

Seed Department

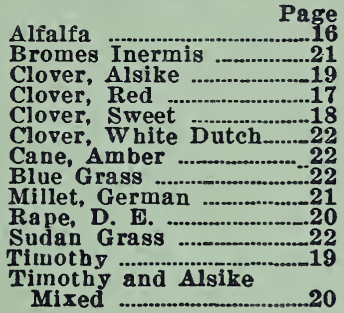

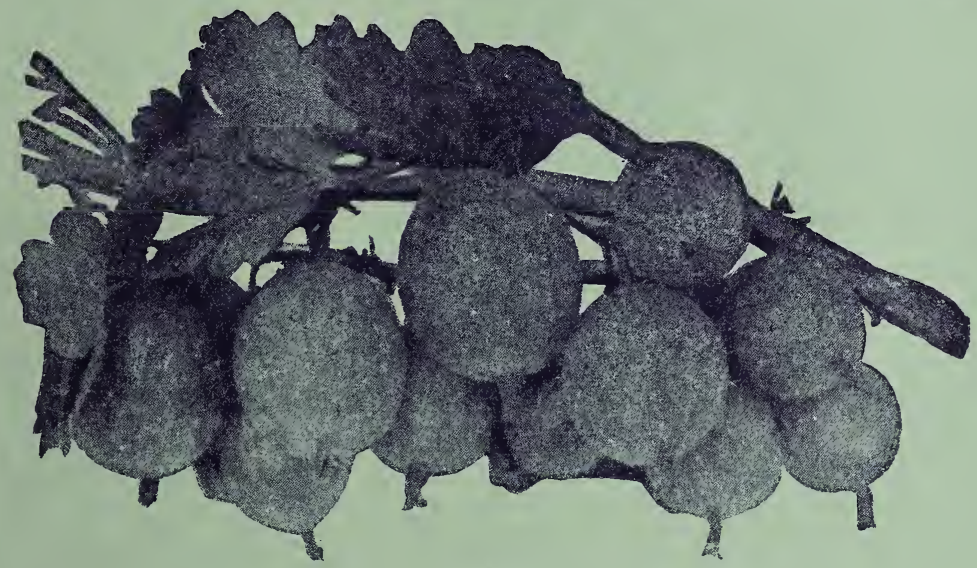

Carrie

If you like gooseberries, plant the Carrie. Largest fruit. Very hardy. Bears second year. Splendid flavor. Very prolific. See prices on page 9.

"Distance lends enchantment." Yes, I know of farmers in my community who send their checks away to distant states for their Farm seed. They do this because the price is cheap, forgetting that they may be sacrificing quality. Now this is poor economy.

This is no reflection on seed men outside of Nebraska, but is it not better to buy your farm seed from a seedhouse of established reputation? 


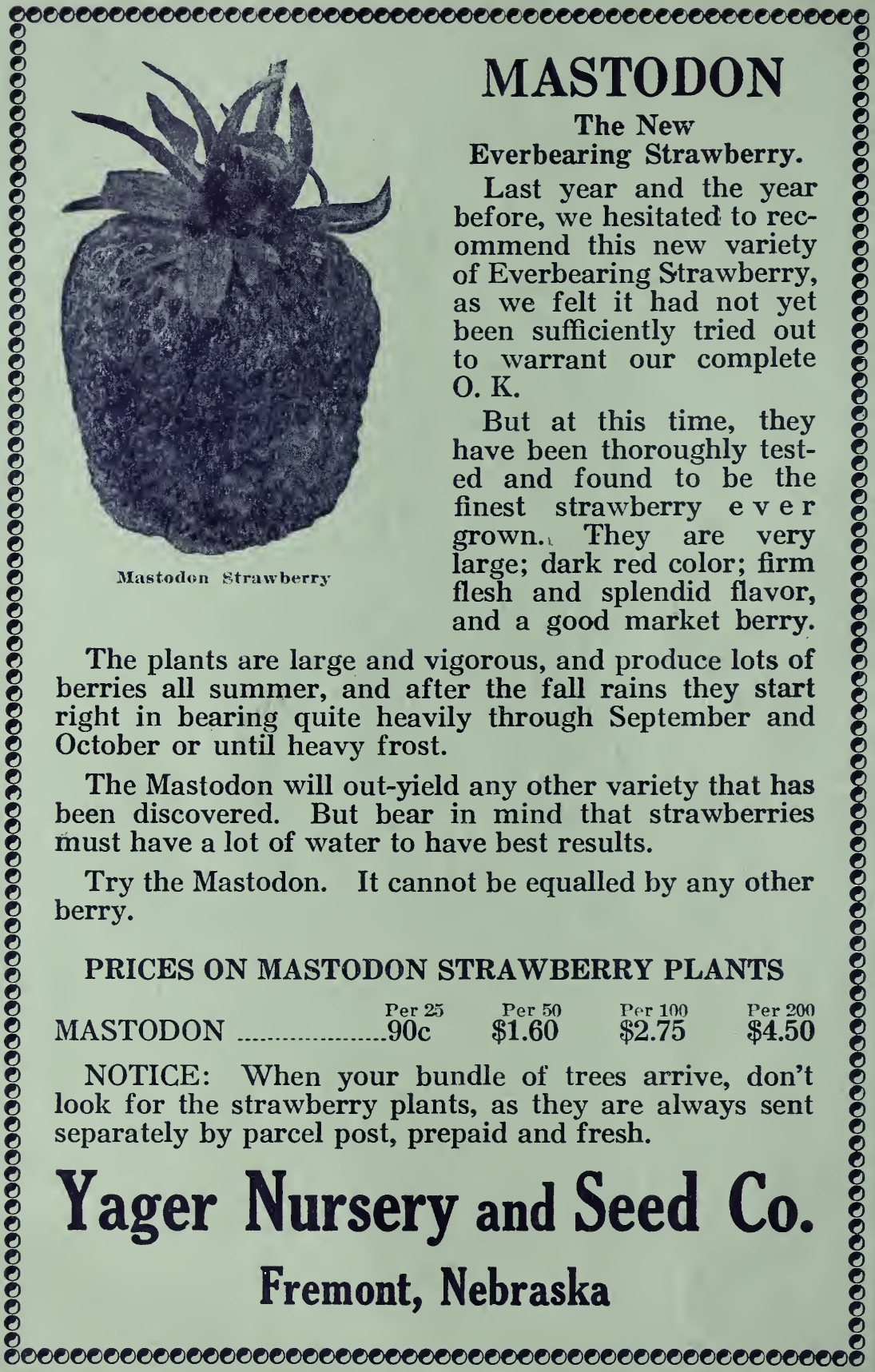

